\title{
Helping Teachers Teach Well: Transforming Professional Development
}

Thomas B. Corcoran

Follow this and additional works at: https://repository.upenn.edu/cpre_policybriefs

Part of the Curriculum and Instruction Commons, Education Policy Commons, and the Teacher Education and Professional Development Commons

\section{Recommended Citation}

Corcoran, Thomas B.. (1995). Helping Teachers Teach Well: Transforming Professional Development. CPRE Policy Briefs.

Retrieved from https://repository.upenn.edu/cpre_policybriefs/74

View on the CPRE website.

This paper is posted at ScholarlyCommons. https://repository.upenn.edu/cpre_policybriefs/74

For more information, please contact repository@pobox.upenn.edu. 


\title{
Helping Teachers Teach Well: Transforming Professional Development
}

\author{
Abstract \\ This brief from 1995 reviews what was known about professional development. The brief discusses its \\ organization, costs, and effects on practice. It also suggests some principles to guide professional \\ development in the future and offers a framework for designing and assessing policies and programs. \\ Disciplines \\ Curriculum and Instruction | Education Policy | Teacher Education and Professional Development \\ Comments \\ View on the CPRE website.
}




\section{Helping Teachers Teach Well: Transforming Professional Development}

\section{by Thomas B. Corcoran}

In virtually every state in the country, reform efforts are dramatically raising expectations for students, and consequently, for teachers. In response to these reform initiatives, educators are being asked to master new skills and responsibilities and to change their practice.

To meet these new expectations, teachers need to deepen their content knowledge and learn new methods of teaching. They need more time to work with colleagues, to critically examine the new standards being proposed, and to revise curriculum. They need opportunities to develop, master and reflect on new approaches to working with children. All of these activities fall under the general heading of professional development.

Historically, state policymakers have paid little attention to the form, content or quality of professional development. Such matters have been left to the discretion of local boards of education and district administrators. However, if today's teachers are to be adequately prepared to meet the new challenges they are facing, this laissez-faire approach to professional development must come to an end. The needs are too urgent and resources too scarce to simply continue or expand today's inefficient and ineffectual arrangements.

This issue of CPRE Policy Briefs reviews what is known about professional development-where it is now, and where it needs to be. The brief discusses its organization, costs, and effects on practice. It also suggests some principles to guide professional development in the future and offers a framework for designing and assessing policies and programs. ${ }^{1}$

\section{Higher Standards and the Practice of Teaching}

Nearly every state in the nation is involved in the movement to raise academic standards. This movement also calls for a shift from a behaviorist approach to teaching, in which students are often passive recipients of teacher-generated knowledge and drill and practice is the primary pedagogy, to approaches which actively engage students in the construction of knowledge.

To make this shift, teachers must enhance their knowledge of subject-matter and learn to use new teaching strategies. Moreover, as a hands-on, studentcentered approach to teaching uses more time to cover less, it requires that choices be made about what content is essential. New assessments are needed that probe students' understanding of content and examine their ability to integrate knowledge and apply it to real

\footnotetext{
Thomas Corcoran is a Senior Research Fellow at CPRE. He is co-directing CPRE's study of state policies and alternative approaches to professional development which is being supported by the Carnegie Foundation. He also is currently playing a lead role for CPRE in the design and conduct of case studies of states for the national program evaluation of the National Science Foundation's State Systemic Initiative being conducted by SRI and CPRE.
}

\section{CONSORTIUM FOR POLICY RESEARCH IN EDUCATION}


life problems. Higher academic standards require far-reaching and difficult changes in the practice of teaching.

Another aspect of current reform is a shift in decision-making authority from the state agency and district central office to the school building. Under schoolbased management, teachers are taking on new roles as members of school governing boards and entering into new relationships with colleagues, school administrators, and parents. These more varied and complex roles demand new skills and new knowledge.

If teachers are to be adequately prepared to work effectively in the classrooms and schools envisioned by reformers, policymakers must establish a coherent and more effective approach to professional development. Teachers and policymakers must abandon longheld conventions about continuing education for teachers and begin to understand professional development as an essential and integral part of teachers' work.

\section{Professional Development Today}

In most districts, professional development is thought of almost exclusively in terms of formal education activities, such as courses or workshops. Several times a year, school administrators release students for a half or full day and hold an "in-service" program that may or may not be relevant to teachers' professional development needs. These programs may feature experts who speak to all teachers on a "hot" topic or they may consist of a number of simultaneous workshops offered by "trainers" (recruited from other districts, the department), with teachers choosing the sessions they wish to attend. Teachers typically spend a few hours listening and, at best, leave with some practical tips or some useful materials. There is seldom any follow-up to the experience and subsequent inservices may address entirely different sets of topics.

District activities are often supplemented by the participation of limited numbers of teachers in professional conferences, workshops offered by regional service agencies or state education agencies, and summer workshops offered by a variety of sponsors. Teachers working in categorical programs receive more of these opportunities because funding is available and special programs are provided for them by state and regional agencies. The amount of this activity depends, in part, on a district's fiscal resources. Who attends depends on the initiative of individual teachers, and on their relationship with school and district administrators, or their willingness to pay their own way.

Salary scales in most districts offer increments to teachers for taking additional coursework or earning continuing education units (CEUs) by participating in various activities. Recertification policies in most states require that teachers earn so many credits or CEUs within a set time (typically five years). Some states require that a master's degree be obtained within a given period in order to obtain a permanent license or in order to reach the highest step in a career ladder. In addition, some districts pay the tuition costs for graduate courses taken by teachers. These state and local policies provide strong incentives for teachers to take graduate courses and be active consumers of workshops and conferences. However, many of these teachers may be seeking qualifications for specialties that will eventually remove them from the classroom.

There is currently no consensus in the field about best practice in professional development, and districts receive little guidance about how to manage and improve their efforts. Innovators are trying some interesting new approaches, and a few states are implementing changes for new teachers, but the vast majority of districts are doing what they have always done.

\section{Costs of Professional Development}

Most states and districts have no idea of what they are actually spending on professional development. They cannot even estimate overall expenditures because the data needed are not available. State accounting systems make it difficult to aggregate professional development expenditures and few districts attempt to track them. However, we do know that local districts bear the brunt of these costs and that much more money is spent on professional development than most policymakers realize.

A study of three urban districts found that district expenditures were up to 50 times the estimates provided by district staff. ${ }^{2}$ Total expenditures ranged from 3.3 percent of the district budget to 5.7 percent. And the cost per teacher ranged from less than $\$ 1,000$ to $\$ 1,767$ in 1980 dollars. In addition to the cost of teacher and administrator time, the study included the costs of workshops and substitutes, salary increases related to degrees and course credits earned, and tuition reimbursement.

A study conducted in California in 1986 found that the average direct expenditure on professional devel- 
opment was $\$ 1,360$ per teacher. ${ }^{3}$ When investments made by individuals and the present value of future salary increments were included, the investment per teacher was over $\$ 4,000$. More than 60 percent of this expenditure was the present value of salary increments earned through professional development. The researchers also found that 90 percent of the total investment was spent on district-controlled activities.

A more recent study by the Education Development Center of four large districts reported per teacher expenditures of $\$ 1,755$ to $\$ 3,529$ annually, representing 1.8 percent to 2.8 percent of local school budgets. ${ }^{4}$ However, the authors of this study did not include the present value of salary increments related to professional development. These fiscal commitments would significantly increase their estimates of investments in professional development.

While these studies used somewhat different definitions of professional development and varied in the expenditures included, they all found higher levels of expenditures than typically assumed by state and local policymakers.

Despite our lack of accurate data on current investment in professional development, we can identify the areas in which investments are made. In most states, local districts bear the brunt of paying for professional development, and their expenditures include: staff costs associated with planning and delivering in-service programs and opening schools for two to five extra days per year for in-service; sending staff to workshops; supervising and evaluating personnel; reimbursing tuition; and paying the salary increments teachers earn when they attain graduate de-

\section{Guiding Principles ${ }^{5}$}

A number of experts and organizations have suggested that the most promising professional development programs or policies are those that:

- stimulate and support site-based initiatives. Professional development is likely to have greater impact on practice if it is closely linked to school initiatives to improve practice.

- support teacher initiatives as well as school or district initiatives. These initiatives could promote the professionalization of teaching and may be cost-effective ways to engage more teachers in serious professional development activities.

- are grounded in knowledge about teaching. Good professional development should encompass expectations educators hold for students, child-development theory, curriculum content and design, instructional and assessment strategies for instilling higher-order competencies, school culture and shared decision-making.

- model constructivist teaching. Teachers need opportunities to explore, question and debate in order to integrate new ideas into their repertoires and their classroom practice.

- offer intellectual, social and emotional engagement with ideas, materials and colleagues. If teachers are to teach for deep understanding, they must be intellectually engaged in their disciplines and work regularly with others in their field.

- demonstrate respect for teachers as professionals and as adult learners. Professional development should draw on the expertise of teachers and take differing degrees of teacher experience into account.

- provide for sufficient time and follow-up support for teachers to master new content and strategies and to integrate them into their practice.

- are accessible and inclusive. Professional development should be viewed as an integral part of teachers' work rather than as a privilege granted to "favorites" by administrators.

grees, college credits, or CEUs. Based on the studies cited above, these activities probably account for 3 percent to 5 percent of local operating expenses.

State investments in professional development include: costs of operating agencies such as intermediate units; state or federal categorical funds set aside for professional development; time provided by state employees for in-service programs or consulting to schools; administrative costs for teacher recertification programs; costs of state-funded conferences or workshops; state subsidies to colleges and universities for courses provided to teachers or for extension services to schools; tuition reimbursements and salary increments for credits for teachers employed directly by the state; and the additional state aid to local districts whose budgets have increased because of teachers salary increases earned as a result of college credits or degrees. 


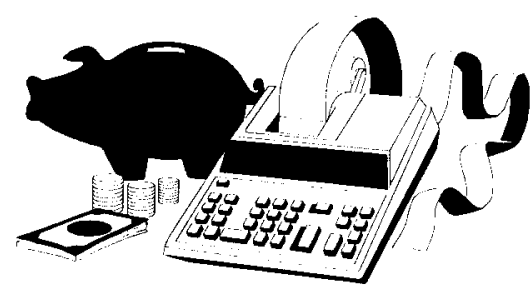

State investments in professional development probably range from less than 1 percent to over 3 percent of total state spending on public education.

The federal government is also making a significant contribution to teacher professional development. According to one recent estimate, the federal government spent \$369 million in fiscal 1993 on teacher development programs in science, mathematics, and technology. ${ }^{6}$ In addition, Chapter Two of the Elementary and Secondary Education Act (ESEA), The Eisenhower State Mathematics and Science Program, allocated \$246 million in the same year.

Legislation passed in 1994 increases federal support for professional development. Most of the funds provided for the states in the Goals 2000 legislation must be passed on to local districts for professional development. The new ESEA increases the funding for the Eisenhower Program (Title 2). Perhaps the biggest changes will be in Title 1 where there will no longer be ceilings on the amounts that can be expended for professional development.

Many reform advocates have called for increased investment in professional development. But, with the lack of good financial information and the absence of standards of program adequacy that could be applied to assess current opportunities for teachers, it is difficult to determine if the resources currently available are adequate or not. At least part of the increased professional development required to support school reforms might be provided by reallocating current investments. Currently, local districts spend a great deal on professional development-and it is typically spent in ineffective ways for unclear purposes.

\section{Impact of the Current System}

There is a growing body of opinion among "experts" that the conventional forms of professional development are virtually a waste of time. In this view, lectures, workshops and other conventional forms of information delivery and training are too topdown and too isolated from classroom realities to have an impact on teachers' practice. Although much of this criticism is probably warranted, there are documented examples of changes in practice resulting from welldesigned training programs. Many of these cases followed the wellknown model of theory-demonstration-practice, feedback, and follow-through advocated by Joyce and Showers (1982) ${ }^{7}$ This model emphasizes the importance of coaching and technical assistance in the classroom. However, the intensive training and frequent follow-up advocated by Joyce and others are rarely used and should not be confused with the one-shot workshops that are more characteristic of staff development in local districts.

On the whole, most researchers agree that local professional development programs typically have weak effects on practice because they lack focus, intensity, follow-up, and continuity. In many cases, neither individual nor organizational activities are closely linked to district goals for student performance. Even where there is substantive linkage, inconsistency and lack of followup weaken potential effects on practice.

\section{Improving Professional Development}

A number of organizations have proposed setting standards for teachers' professional development. The guiding principles behind these ideas are summarized in the sidebar on page 3. Standards might help improve the quality and efficiency of professional development. However, while these proposals are useful for discussion, it is important that state and local policymakers engage teachers in the process of setting standards for states or districts. Teachers have a great deal of insight into what has made professional development effective or ineffective in the past, and will be more likely to support changes to the current system if they have been a significant part of the improvement process.

\section{Promising Policy Options}

To make professional development more effective and more consistent with the guiding principles outlined in the sidebar on page 3 , policymakers need to be clear about the problems they are trying to solve and about the conditions under which teachers are likely to change their practice. They must also be more concerned about the quality and character of experiences provided for teachers. And, given the scarcity of resources, they must strive to be efficient, to leverage additional resources, and to make full use of expertise already in the system.

Fortunately, some policymakers and practitioners have come up 
with new approaches that are promising, though we know little about their costs or effects as yet.

These approaches to teacher professional development are consistent with the guiding principles outlined in the sidebar on page 3 and share some common characteristics. They respect the expertise of accomplished teachers. They are integrated with teachers' work. They are based on current research on teaching and learning. They recognize teachers as a valuable source of information regarding effective professional development and include them in its design and implementation. The examples below are good starting points for incorporating these ideas.

Joint Work and Job Enrichment. Joint work refers to shared responsibility for tasks, such as in team teaching, curriculum committees, or other jobs that create interdependence among teachers and require cooperation. Joint work promotes learning on the job because it provides opportunities for productive exchange among teachers and reflection about practice. Job enrichment refers to the expansion of teachers' work in ways that require new skills, such as the scoring of portfolios in Vermont or serving as mentors to beginning teachers in Connecticut. These new responsibilities include opportunities for teachers to discuss their practice and share ideas.

Teacher Networks. Teacher networks tend to focus on specific subject-matter and seek to deepen teachers' understanding of content and their facility with new teaching strategies. They offer teachers access to a "professional community" in which their expertise and experience are respected and where they can be active participants in professional discourse about improving practice.
Networks have high credibility with teachers, and appear to have positive effects on their motivation, knowledge of pedagogy and subject-matter, willingness to take risks, and commitment to improvement. The National Writing Project, Urban Math Collaboratives, California's subjectmatter collaboratives and Vermont's portfolio networks are examples of teacher networks.
Collaborations Between Schools and Colleges. Professional development opportunities cannot be provided in sufficient intensity and for sufficient numbers of teachers unless the schools and colleges work together. Some organizations, such as the American Association for Higher Education and its affiliate, the Education Trust, as well as the Carnegie Corporation of

\section{Finding Time for Professional Development}

Watts and Castle $^{8}$ outline five approaches that have been used to create more time for professional development:

1. Using substitutes or releasing students. Some schools are effectively using one morning or afternoon a week for teacher development and other improvement activities. However, this approach provides only small blocks of time and is often resented by parents.

2. Purchasing teacher time by using permanent substitutes, retirees, or giving compensation for weekends or summer work. This is expensive, sporadic, and some teachers will not participate on weekends or during the summer.

3. Scheduling time by providing common planning time for teachers working with the same children or teaching the same grade on a regular basis. This is often done in schools using instructional teams, but it could be done in many more schools if assistance was provided with block scheduling.

4. Restructuring time by permanently altering teaching responsibilities, the teaching schedule, school day, or school calendar. This has serious implications for busing, union contracts, facilities maintenance, state regulations, and budgets. It also means changing public expectations-a reason few schools or districts have taken this approach.

5. Making better use of available time and staff.

In contrast to $\mathrm{K}-12$, postsecondary classes are typically not expected to meet daily and faculty rarely teach more than three classes a semester. In Japan and China, teachers spend only three to four hours in the classroom and have the remainder of the day for professional work. This option is often regarded as too costly, but the costs could be minimized by:

- substituting appropriate television programming for regular instruction occasionally;

- using adult volunteers or older students to provide extracurricular activities for children;

- using occasional large classes for special topics, for exposure to the arts, or presentations of outside "experts";

- using independent study to let students pursue projects on their own; and/or

- involving more students in community service activities. 


\section{A Framework for Reviewing Professional Development Policies and Practices}

A. How is professional development defined by teachers, district administrators, state officials, and legislators? How is it defined in collective bargaining agreements and in law and regulation?

- What activities fall within these definitions? What falls outside of them?

- Are prevailing definitions consistent with current thought about high-quality professional development?

- Is participation in professional tasks that leads to acquisition of new knowledge or skills treated as professional development?

- How much responsibility for professional development is placed on the teacher, on the school, and on the district?

- Who decides the amount and content of professional development?

B. What growth opportunities are being provided for teachers?

- Is support provided for beginning teachers?

- Are growth opportunities built into teachers' workdays?

- Do teachers have regular opportunities to work together?

- Are teachers performing professional or administrative tasks requiring significant skills ?

- Do the state colleges and universities provide appropriate courses accessible to all teachers?

- How much time is set aside for professional development?

- Do these opportunities vary across districts, schools, and grade levels?

C. What are the incentives for teachers to participate in professional development and to improve their practice?

- Is professional development linked to personnel evaluation and recertification?

- Do districts reimburse college tuition for graduate study?

- Are salary increments linked to professional development?

- Does professional growth bring increased responsibility, status, or recognition?

- How do the incentives affect teachers in different locales, grade levels, or career stages?

D. Who sponsors and provides formal professional development?

- What are the roles played by schools, districts, immediate units, institutions of higher education, state education agencies, and/or professional associations?

- Is there collaboration among these agencies to improve quality and reduce redundancy?

E. What is known about the effects of existing policies and programs?

- Are evaluations conducted?

- Are there data on participation rates by categories of activity and teachers?

- Are there data linking specific experiences with changes in practice and/or improvements in student performance? 


\section{F. How is professional development planned and coordinated?}

- Is there a state plan(s) and are there state priorities?

- Do schools and/or districts have to develop plans? If so, what are the criteria for approving the plans?

- Are local professional development activities tied to school improvement?

- Is there coordination of activities within the state agency and between K-12 and higher education?

- Is there coordination among providers?

\section{G. What is regarded as "good practice" in professional development?}

- Are there "standards" or guidelines?

- What do the outstanding districts do?

- What do the "best" providers do?

- What activities do teachers feel have the most value?

- How do these "good practices" match up with proposed standards, and what is known about their impact on practice?

\section{H. How is professional development funded?}

- How much is allocated for direct state and local expenditures on professional development?

- What is the cost of tuition reimbursements? of conference and workshop expenses?

- What is the cost of teacher salary increments resulting from educational experiences?

- How much do teachers personally spend on professional development?

- How much instructional time is lost annually? What is its cost?

- What state subsidies are given to providers of professional development?

I. How is professional development linked to the improvement of teaching and to the changes in standards, curriculum, and assessment envisioned by systemic reform?

- Are teachers required to develop professional improvement plans?

- Are teacher salary increments dependent on the job-relatedness of the activities?

- Are state initiatives to set standards and develop curriculum frameworks and new assessments supported by appropriate professional development?

\section{J. To what extent are current activities consistent with principles for effective professional development? Do they:}

- Stimulate and support site-based initiatives?

- Support teacher initiatives as well as school or district initiatives?

- Build programs on the knowledge base about teaching?

- Offer teachers opportunities to be active learners?

- Offer intellectual engagement with ideas, materials, and colleagues?

- Demonstrate respect for teachers as professionals and as adult learners?

- Provide for sufficient time and follow-up support for teachers to master new strategies and content, and integrate them into their practice?

- Ensure that professional development is accessible and inclusive? 
New York, Ford Foundation, Knight Foundation, the Pew Charitable Trusts, and the Rockefeller Foundation are actively promoting and supporting partnerships between colleges and schools. While these initiatives vary in size and focus and remain quite fragile, dependent in many instances on external funding and often operating at the margins of the institutions, they hold great promise for strengthening professional development. As current reforms require teachers to deepen their knowledge of subject-matter, it is important that these initiatives involve liberal arts faculty as well as those in schools of education.

\section{Professional Development} (or Practice) Schools. Professional development schools are a special form of collaboration between public schools and higher education. The Association for Supervision and Curriculum Development has documented several hundred of these institutions which are roughly analogous to teaching hospitals. While much attention has been given to their potential role in the pre-service preparation of teachers, they also could play an important role in professional development. They could bring both novice and experienced teachers together with university clinical faculty in a professional setting to improve their practice through observation, low- risk experimentation, reflection and coaching.

\section{National Board Certification.} The National Board of Professional Teaching Standards has worked with teachers and national teacher organizations to establish standards and assessment procedures for recognition of exemplary teachers. The Board hopes that teachers who achieve "national board certification" will be given responsibilities commensurate with their abilities, such as mentoring beginning teachers or developing curricula, and that local policymakers will use its standards to guide their professional development programs. The process of applying for certification itself is thought to be excellent professional development for teachers as it requires them to document their practice, reflect on their strengths and weaknesses, and demonstrate specific knowledge and skill.

Teachers as Researchers. Increasing numbers of teachers are conducting research in their classrooms and schools in cooperation with their colleagues and university faculty. While some of these research projects are defined by academic interests, many are directed at problems identified by the teachers themselves. There is considerable evidence that involving teachers in research can stimulate discussion, help organizations define problems, and lead to changes in practice and policy.

\section{Implications for Policymakers.}

Given these and other options for improving professional development for teachers, what steps should policymakers be taking? To begin with, they should focus their deliberations on the central issues of professional development and set some clear goals for policy. These goals might include the following.

- Focusing professional development on core problems of teaching and learning. Teachers need more opportunities to become intellectually engaged with their subjectmatter and to deepen their understandings of key concepts. They need opportunities to try new approaches in environments that are supportive.

- Balancing individual and organization- interests in professional development, and restructuring incentives so that they are more closely aligned. Professional development arrangements should support schoolwide improvement, stimulate individual growth and engagement in teaching, and support career advancement.

- Embedding more professional development in the workplace so it is more closely related to teachers' work experience. Teachers should have access to their colleagues and be encouraged to share, discuss, and reflect on their practice. Time must be provided for these collegial activities.

- Ensuring that high-quality professional development opportunities are accessible to teachers who serve the most vulnerable stu-

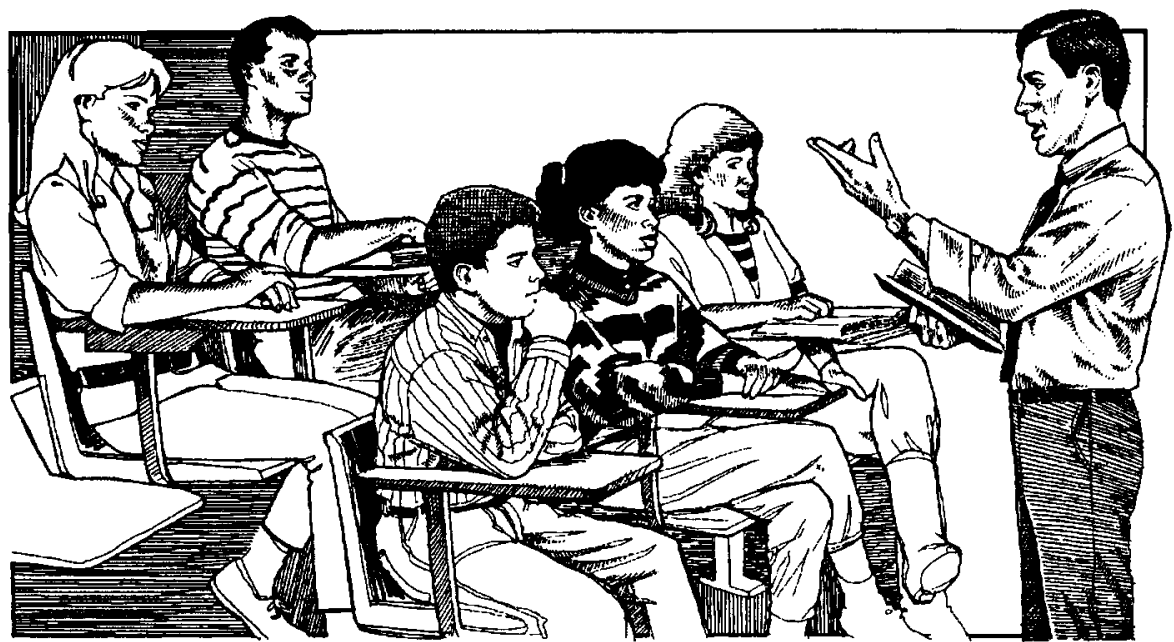


dents. The teachers of the children of the poor, of isolated minorities, of immigrant families, and others who are at high risk of failure in the schools often work under the most difficult conditions and have less time for interaction and less opportunity to improve their practice.

- Improving the productivity of professional development. We cannot afford the laissez-faire, inefficient approach that has been taken to professional development. We need standards for schools and for providers, technical assistance in design and implementation, and monitoring to ensure that funds are targeted and well-used. This is especially important in low-performing schools.

Given these policy goals, there are clearly some actions that state policymakers should avoid. It would make little sense to expand the resources devoted to professional development without attending to improvements in quality. Given the sparse evidence about what works, it makes sense to avoid heavy investments in any single approach to professional development. All professional development strategies should be treated as hypotheses to be tested, and encouraging multiple strategies would be more prudent than mandating a single approach.

Policymakers should also be aware of the risks of focusing solely on the short-run, immediate needs generated by the implementation of school reforms. Improving teaching is a long-term problem. Focusing on the short-term can lead to superficial compliance with new policies and the neglect of long-term investments in teachers' knowledge of subject-matter and pedagogy.

What steps might state policymakers take to push professional development in the right direction? There are several areas in which action by state leaders could produce benefits.

- Increasing awareness among educational leaders. Policymakers should reach out to key stakeholders such as local board members, school administrators, teacher leaders, and university faculty and engage them in discussions about the adequacy of existing professional development opportunities and the alternatives. Many individuals have stakes in the current arrangements and these audiences need to be convinced that new forms of professional development are required to effectively support reforms in standards, curriculum, and instruction.

\section{- Increasing public support and} awareness. The public also must be convinced that new forms of professional development are needed and that time and money should be allocated to support them. Parents hear from teachers that professional development is ineffective and do not want more time and money wasted on it. Since more than 80 percent of existing professional development funds are locally controlled, the support of local communities is critical to the strengthening of professional development.

- Reviewing Policies and practice. State policymakers should take advantage of new federal initiatives and review the policies, practices, and programs that shape professional development in their states. A thorough policy review is essential to determine what changes in structures and incentives, if any, are needed to support the reform agenda in a particular state. A framework for such a review is presented on pages 6-7.

- Setting standards and priorities. Standards could provide much- needed guidance for both state and local professional development activities. If state policymakers adopt guidelines for the design, character, conduct, and content of professional development, based on input from educators and linked to state performance and content standards, they could enhance the likelihood that the time and resources dedicated to professional development are put to good use.

- Providing more time. States must increase the time available for teacher interaction and professional development. Some common approaches that might be used to create more time for professional development are presented in the sidebar on page 5 .

- Strengthening teacher roles. The all-to-common failure to involve teachers in the planning and delivery of professional development undermines its legitimacy and efficacy. The failure to use exemplary teachers to lead professional development wastes talent, increases costs, and contributes to the division between research and practice. States could lead the way by making more use of outstanding teachers in their own professional development activities, linking professional development to school-based management-shifting both the responsibility and the funds to the school site, and involving teachers in setting standards for professional development and recertification. A number of states have already taken such steps.

- Supporting local adoption or demonstrations of promising approaches. The alternative approaches to professional development described above are sufficiently promising to warrant state support for local initiatives or for the implementation of demonstration projects. 
- Re-thinking incentives. Policymakers should consider altering the incentives affecting teachers' participation in professional activities by permitting service to "count" toward recertification, especially if the service involves research or reflection on good practice, learning new content or skills, and/or teaching or mentoring. They may consider using teacher portfolios for recertification. They might even consider eliminating the award of CEUs for workshops or in-service experiences that do not meet minimum standards for quality, or giving salary increments only for graduate coursework that is related to teachers' current or future assignments. They might even want to expand existing subsidies for advanced study in content or pedagogy for all teachers or for teachers from low-performing schools.

\section{Conclusion: Going to Scale}

Action is necessary. The current arrangements for the professional development of teachers too often lead to unfocused, fragmented, low-intensity activities that do not lead to significant changes in teaching practice. A different mindset is needed if professional development is to contribute to strengthening the profession and improving the schools. New approaches are needed to support the implementation of more rigorous standards, new curriculum frameworks, performance assessment, and changes in school organization and governance.

Before state policymakers can take action, however, it is important that they carefully review the current system of professional development in their states. The outline on pages 6-7 sessing current state policies and practices regarding teacher professional development, and will help stimulate thinking about ways to improve it.

Perhaps the greatest challenge will be to develop the capacity to extend new approaches to the 2.4 million teachers working in 85,000 schools in the United States. Given current capacity and budget constraints, it seems an impossible quest to design, organize, fund and operate professional development initiatives that would involve all teacherseven all those in a single stateand successfully engage them in a process of reflection, growth, and improvement of practice. And the task will be virtually impossible if we continue to define the problem in this manner.

Going to scale itself requires a fresh mindset and new approaches. It means using all policy levers available to the state-aid to higher education, accreditation, certification and recertification requirements, and teacher compensation structuresto deliver a consistent message to teachers and local policymakers and administrators. Local policies and practices must change if teachers are to receive appropriate opportunities to learn. State and local policymakers must be willing to re-allocate resources and redirect existing channels for professional development so that they are supportive of desired reforms.

Going to scale also requires changing the incentive structure for teachers to encourage them to seek knowledge and skills that they need. It means taking full advantage of every opportunity for professional growth-curriculum development, assessment programs, and teacher conventions. It means building new collaboratives and partnerships to mobilize and coordinate public and private resources. It requires making greater use of teacher and school networks, electronic networks and educational and cable television, to reinforce the message, help teachers acquire necessary skills and support their efforts to change. Finally, it means adopting a different timeframe and making a long-term commitment to reform based on a coherent set of principles and policies.

Reforming teacher professional development may sound like an impossible task, but engaging all teachers in discussions of good practice and supporting their efforts to learn and to use more effective pedagogy may be the first real step towards higher standards for all children.

\section{Endnotes}

1.This brief excerpts material from Thomas B. Corcoran, Transforming Professional Development for Teachers: A Guide for State Policymakers (Washington, DC: National Governors' Association, 1995). The work was supported by a grant from the Carnegie Corporation of New York. The views expressed here are not necessarily those of NGA, Carnegie, or the Consortium for Policy Research in Education.

2. D. Moore and A. Hyde, Making Sense of Staff Development: An Analysis of Staff Development Programs and Their Costs in Three Urban Districts (Chicago, IL: Designs for Change, 1981).

3. J. W. Little and others, Staff Development in California: Public and Personal Investment, Program Patterns, and Policy Choices (San Francisco: Far West Laboratory for Research and Development, 1987); D. S. Stern, W. H. Gerritz, and J W. Little, "Making the Most of the Districts Two (or Five) Cents: Accounting for Investments in Teacher Professional Development," Journal of Education Finance 14: 19-26 (1989). 
4. Miller, B., B. Lord, and J. Dorney. Staff Development for Teachers: A Study of Configurations and Costs in Four Districts. (Newton, MA: Education Development Center, 1994).

5. Griffin, G. 1982. "Staff Development." Paper prepared for the National Institute of Education Invitational Conference, Research on Teaching: Implications for Practice, Arlie House, VA. Washington, DC, National Institute of Education; Hodges, H. 1994. "Using Research to Inform Practice in Urban Schools: 10 Key Strategies for Success. Paper prepared for the Invitational Conference on "Improving Urban Schools: Better Strategies for Dissemination and Knowledge Utilization," sponsored by the National Center on Education for the Inner Cities, Alexandria, VA, September 8-10; Joyce,
B., and B. Showers, 1982. "The Coaching of Teaching." Educational Leadership, 40(1): 4-10; Little, J.W. 1993. "Teachers' Professional Development in a Climate of Reform." Educational Evaluation and Policy Analysis 15(2):129-151; LoucksHorsley, S., C.Harding, M. Arbuckle, L. Murray, C. Dubea, and M. Williams. 1987. Continuing to Learn: A Guide Book for Teacher Development. Andover, MA: Regional Laboratory for Educational Improvement of the Northeast and Islands and the National Staff Development Council; Price, H. 1993. "Teacher Professional Development: It's About Time." Education Week, 12(33), 32; National Staff Development Council. 1994. National Staff Development Council's Standards for Staff Development: Middle level Edition. Oxford, OH: author; Zim- pher, N. L., and K. R. Howey. 1992. Policy and Practice Toward the Improvement of Teacher Education. Oak Brook, IL: The North Central Regional Educational Laboratory.

6. Federal Coordinating Council for Science, Engineering, and Technology, The Federal Investment in Science, Mathematics, Engineering, and Technology Education: Where Now? What Next? (Washington, DC: National Science Foundation, 1993).

7. B. Joyce and B. Showers, "The Coaching of Teaching," Educational Leadership 40(1): 4-10 (1982).

8. Watts, G.D., and S. Castle. "The Time Dilemma in School Restructuring." Phi Delta Kappan 75:306-310 (1993).

\section{Recent Reports and Related Publications}

The Outlook for School Revenue in the Next Five Years Steven D. Gold, May 1995 (RR-034), 28 pp., \$10.00

This paper examines the outlook for school finance over the next five years. The environment for increases in real school revenue per pupil in the rest of the 1990s will not be favorable. The most significant problem is likely to be reductions in federal aid to states. States will respond to decreases in federal aid for social and health programs by trimming increases in state education aid. Other negative factors will be continued strong competition for state tax dollars from corrections and health programs and conservative state tax policy. A dynamic economy will benefit schools in selected states, but the overall rate of economic growth is likely to be moderate at best. Although some states will shift reliance away from property taxes, most states will not do so.

\section{Ruling Out Rules: The Evolution of Deregulation in State Education Policy}

Susan H. Fuhrman and Richard F. Elmore

March 1995 (RR-033), 34 pp., \$10.00

This paper examines the evolution of deregulation from limited waiver programs to charter programs and new performance-based accountability systems that include broad-scale deregulation. Early deregulation programs were so limited in design that they had very modest results, but policymakers are finding expanded efforts very difficult to achieve. Many of the same political forces and habits of practice that limited early efforts continue to pose barriers to deregulation. Underlying the barriers is an historic, continuing uncertainty about the state role and about how states should relate to districts of varying types.

\section{Teachers' Professional Development and Education Reform CPRE Policy Briefs (No. RB-11-10/93)}

This brief addresses the problem of "fit" between current state and local reforms and prevailing approaches to professional development. The first section summarizes the major themes of reform; the second focuses on the policy dilemma these reforms present for professional development; the third describes emerging alternatives to traditional professional development; and the final section suggests principles to guide the design of professional development opportunities.

How to Order CPRE Publications: To obtain copies of Research Reports or Briefs write: CPRE University of Pennsylvania 3440 Market Street, Suite 560 Philadelphia, PA 19104-3325

(Add $\$ 10$ shipping and handling for delivery outside the U. S.) For information on quantity discounts (over 25 copies), call 908/932-1331. Sorry, we cannot accept returns. All orders must be prepaid with U. S funds from U. S. banks; make checks payable to CPRE. 